\title{
Overview of European Universities with Open Distance Learning
}

\author{
Julia Tsarapkina ${ }^{1, *}$, Elena Lyapunzova ${ }^{2}$, Alena Anisimova ${ }^{3}$, and Alexei Mironov ${ }^{4}$ \\ ${ }^{1}$ Russian State Agrarian University - Moscow Timiryazev Agricultural Academy, Timiryazevskaya \\ 49, 127550 Moscow, Russia \\ ${ }^{2}$ Bauman Moscow State Technical University, 2-ya Baumanskaya st. 5/1, 105005 Moscow, Russia \\ ${ }^{3}$ Volokolamsk agricultural College «Kholmogorka», 39, 143602 Ivanovskoe, Russia \\ ${ }^{4}$ Krasnoyarsk state agrarian university, Mira Avenue 90, 660049 Krasnoyarsk, Russia
}

\begin{abstract}
Currently, distance learning is becoming the most attractive for the implementation of educational programs of open universities. These educational institutions are becoming the most popular in the context of continuing education. The article presents a study of European open universities with distance learning, which are members of the EADTU. The paper describes the main characteristics of European open education, describes the characteristics of the universities studied based on data posted on the websites of these educational organizations. The aim of the study is to analyze and compare digital educational platforms of open universities with distance learning. Methods of information search, comparison and analysis, statistical analysis and rating compilation were used. The authors used information about site traffic provided by the service Pr-cy.ru. The article presents an analysis of statistical data on the attendance of digital educational platforms according to the following criteria: the number of visitors per day, the average time spent on the site, the belonging of visitors to a geographical region. Based on the obtained statistical data, the ratings of open universities with distance learning were compiled. The paper reveals the main common features inherent in European universities that are part of the EADTU. The data obtained in the course of the study can be used to further study the experience of implementing open distance learning in the context of continuous learning.
\end{abstract}

\section{Introduction}

Nowadays, there is a pronounced trend towards widespread use of distance technologies in the field of higher education. The level of development of information technology allows us to meet the needs for remote support of the educational process. The issue of accessibility and quality of education in this context plays an important role, especially in the field of higher education [1].

The Euro-pean Association of Distance Teaching Universities (EADTU) has been established in Europe. EADTU consists of 25 European countries represented by online

\footnotetext{
${ }^{*}$ Corresponding author: julia_carapkina@mail.ru
} 
universities, open and distance learning universities, national university assemblies or individual universities. This organization was created to support open and distance higher education, its modernization in European universities. European open distance education has the following characteristics [2]:

- Studying is focused on students, based on the high quality of the educational digital environment;

- openness to students through flexible individual and inclusive forms and methods of teaching, which allow students to receive higher education using information technology.

- networked education and mobility, allowing students to learn regardless of nationality, industry and institutional boundaries.

The term open university is of English origin, as they call educational organizations created with the aim of providing wide access to higher professional education [3]. Anyone can enroll in such a university, regardless of the level of existing education. Education is carried out remotely, as well as through the contact of students and teachers in a digital environment [4]. To obtain a diploma on graduation from the university, a student must master several courses.

EADTU offers its expertise in online education for students and higher education institutions to ensure that online learning at all European universities meets the highest quality standards [5].

The adopted concept of lifelong education sets the educational system to modernize and develop new forms of building the educational process [6]. Distance continuous vocational education is the most promising form of training and retraining of specialists, which is characterized by flexibility, dynamism and meets the needs of the economy [7-8]. From this perspective, an example of the work of open distance universities is interesting.

The aim of our work is to study and compare educational digital platforms of European open universities with distance learning, members of EADTU.

In accordance with the set goal, we have implemented the following tasks: to characterize the open universities included in EADTU; analyze and compare statistical data on the operation of educational digital platforms of the universities in question; compile a rating of open universities with distance learning based on the data obtained; to reveal the main common features of European open universities with distance learning;

In our work, we would like to refer to the experience and existing practices of training specialists in European countries.

\section{Methology}

In our work, we would like to characterize European universities with open distance learning based on the analysis of data presented on the websites of these organizations.

The paper also presents a comparative analysis of educational platforms of open universities with distance learning included in EADTU with the help of Pr-cy.ru. This service is designed to conduct SEO analysis of sites, display traffic data [10]. Site statistics are presented in average values. For the analysis we have selected the following indicators: the number of visitors per day; average time spent on the site; the geographic region of the visitors.

\section{Results}

In the course of our work, we researched and analyzed data from the websites of European open universities that are members of EADTU. Of interest was information on the date of 
creation of universities, the number of students enrolled, the number of online courses posted on digital educational platforms, directions and levels of training of students.

Characteristics of open universities with distance learning based on the data presented on the websites of educational institutions:

FernUniversität in Hagen is a state distance university in Germany. Distance learning has been conducted here since 1974, every year the university issues diplomas of completion of bachelor's and master's programs to thousands of students from Germany and other countries. A total of 88 thousand students study at the university. The university provides training in 4 areas: humanities and social sciences, mathematics and information, economic sciences, jurisprudence. The platform offers a full set of online courses for obtaining working specialties free of charge, but the university collects fees of 200-400 euros per semester for administrative and student needs. About 300 new video lectures appear on the platform every year.

International Telematic University UNINETTUNO - International Telematic University UNINETTUNO was founded in 2005 in Italy and unites 43 Italian and foreign universities. The online distance courses are available in Italian, English, Arabic, French and Greek and include multimedia products, exercises, assessment and self-assessment systems, digital library resources, and chat and forums. Students can study at 8 faculties: the Faculty of Communication, Media and Advertising, the Faculty of Economics, the Faculty of Engineering, the Faculty of Modern Languages, the Faculty of Law, the Faculty of Literature, the Faculty of Psychology and the Faculty of Professional Education for Adults. The platform contains about 1000 online courses, distributed by specialties and areas of training. Training is carried out on a paid basis.

Hellenic Open University -is a Greek open university in Patras. Students study at this educational institution exclusively in a distance format. Education is carried out in 4 faculties: humanities, social sciences, science and technology, applied arts. Graduates can study in undergraduate, graduate, postgraduate and MBA programs only on a paid basis. Online courses are presented in Greek and English.

Open University of Cyprus APKY - is the Open University of Cyprus. It is a public university that was founded in 2002 to fill a gap in the higher education system in Cyprus. The platform presents programs for training in the magistracy and a fairly wide range of areas of postgraduate and doctoral studies. This educational institution offers distance learning at 3 faculties in 26 specialties. 4000 people study at the university. Also, the Platform implements short-term distance learning courses in the field of entrepreneurship and innovation. Education for EU citizens is free. A distinctive feature of this platform is the group work of students in the process of mastering online courses [11].

The Open University $U K$ is the world's leading provider of flexible and high quality online distance learning courses. Has triple MBA accreditation. The platform has about 2 million users. 452 online courses on 200 specialties are available for training. The university was founded in 1969 and is one of the most prestigious universities in the UK. Currently, the academic institution includes the Faculties of Arts \& Social Sciences, the Faculty of Business and Law, the Faculty of Science, Technology, Engineering and Mathematics (Faculty of Science, Technology, Engineering and Mathematics), as well as the Faculty of Wellbeing, Education, Languages, and Sport. In 2013, OU launched a Massive Open Online Courses (MOOC) platform called Future Learn, which is the UK's largest provider of free online courses [12].

Open Universiteit Niederland created in the Netherlands in 1984, modeled on the Open University of Great Britain. This educational institution offers undergraduate and graduate programs in management, computer science, psychology, law, cultural studies, ecology and natural sciences. There are 738 online courses on the platform. Training takes place in an online format, students are provided with access to educational materials, the student must 
independently follow lectures and group meetings in a digital environment. Before registering for courses, students are invited to pass a self-test in order to determine whether the distance learning format is suitable for the student or not [13]. Courses are presented in Dutch and English. The university has about 1000 students.

Universidad Nacional de Educación a Distancia (UNED) -National University of Distance Education of Spain, founded in 1972. Currently, the university has training centers in 13 countries in Europe, America and Africa. Currently, about 150 thousand students study on the platform. The university ranks second in the world in terms of student enrollment. Education is carried out on a free basis, however, there is a competitive selection for admission to this educational institution, the progress and quality of the entrance tests are taken into account. In 2012, the university launched a new online platform for entrepreneurship learning by building mobile apps using App Inventor [14]. UNX Online Courses are designed to introduce the entire Spanish-speaking world to open technology and entrepreneurship.

Universidade Aberta (UAb) - The Open University of Portugal, has been engaged in distance learning since 1988. It prepares students for baccalaureate, master's and doctoral programs in 33 countries on five continents. The main languages of instruction are Portuguese and English. More than 10 thousand students are trained on the platform annually. Since 2008, when all programs are taught in e-learning mode, UAb has become a European reference institution for advanced e-learning and online learning through recognition of its exclusive virtual pedagogical model. In 2010 he was awarded the European Foundation for E-Learning Quality EFAUEL in Higher Education.

Universitat Oberta de Catalunya (UOC) -The Open University of Catalonia was founded in 1995 as the world's first online university. Education is conducted in 25 undergraduate programs and 54 graduate programs and 8 doctoral programs. The courses offered are presented in 7 faculties: Arts and Humanities, Economics and Business, Medical Sciences, Information and Communication Technologies, Computer Science, Multimedia and Communication, Law and Political Science, Psychology and Pedagogical Sciences. 77 thousand people are trained on the platform.

In accordance with the tasks set in the study, based on the data obtained, we analyzed the digital educational platforms of the universities under study. Table 1 presents data on site traffic collected using the Pr-cy.ru service.

The first place in the ranking by the number of website visitors per day is taken by The Open University UK. According to the statistics of attendance, $59.1 \%$ of students from the UK, $40.9 \%$ of students from the United States study on the digital platform of the university. On average, students spend 10 minutes on the digital education platform. The Open University of Cyprus APKY website has the lowest daily attendance rate - 3800 people. Almost all students studying on the platform - 98.1\% - represent Cyprus.

The first place in the ranking in terms of the breadth of the geographical coverage of students belongs to the Universitat Oberta de Catalunya (UOC). According to website traffic statistics, $50.7 \%$ of the students of the open university are from Spain, $11.3 \%$ and $11.2 \%$ of students, respectively, are from Mexico and India, the remaining $26.8 \%$ of students are from various European countries.

Table 1. Statistical data of the analysis of websites of open universities with distance learning

\begin{tabular}{|l|l|l|l|l|}
\hline & $\begin{array}{l}\text { Name of the open university with } \\
\text { distance learning, website }\end{array}$ & $\begin{array}{l}\text { Number of } \\
\text { visitors per } \\
\text { day }\end{array}$ & $\begin{array}{l}\text { Belonging to a } \\
\text { geographic } \\
\text { region }\end{array}$ & $\begin{array}{l}\text { Time spent } \\
\text { on the site }\end{array}$ \\
\hline $\begin{array}{l}\text { The Open University UK } \\
\text { http://www.open.ac.uk/ }\end{array}$ & $\begin{array}{l}197000 \\
\text { Universidad Nacional de Educación a } \\
\text { Distancia (UNED) }\end{array}$ & $59.1 \%$ & $10 \mathrm{~min}$. \\
\hline
\end{tabular}




\begin{tabular}{|l|l|l|l|l|}
\hline & https://www.uned.es/ & & & \\
\hline 6 & $\begin{array}{l}\text { Universitat Oberta de Catalunya (UOC) } \\
\text { https://www.uoc.edu/ }\end{array}$ & 125000 & $50.7 \%$ & $22 \mathrm{~min}$. \\
\hline \hline & $\begin{array}{l}\text { Hellenic Open University } \\
\text { https://www.eap.gr/ }\end{array}$ & 39100 & $97.7 \%$ & $8 \mathrm{~min}$. \\
\hline $\begin{array}{l}\text { Fern Universität in Hagen } \\
\text { https://www.fernuni-hagen.de/ }\end{array}$ & $\begin{array}{l}\text { Open Universiteit Niederland } \\
\text { https://www.ou.nl/ }\end{array}$ & 15700 & $80.8 \%$ & $11 \mathrm{~min}$. \\
\hline $\begin{array}{l}\text { International Telematic University } \\
\text { UNINETTUNO } \\
\text { https://www.uninettunouniversity.net/ }\end{array}$ & 10700 & $99.8 \%$ & $6 \mathrm{~min}$. \\
\hline $\begin{array}{l}\text { Universidade Aberta (UAb) } \\
\text { https://portal.uab.pt/ }\end{array}$ & $\begin{array}{l}\text { Open University of Cyprus APKY } \\
\text { https://www.ouc.ac.cy/ }\end{array}$ & 3800 & $98.1 \%$ & $6 \mathrm{~min}$. \\
\hline
\end{tabular}

The Universitat Oberta de Catalunya (UOC) also ranks first in the ranking in terms of the amount of time spent by visitors on the platform. On average, visitors spend up to 22 minutes on the site per session, more than double the time that visitors spend on other educational digital platforms we are looking at. Visitors to Universidade Aberta (UAb) spend the least time on the site -3 minutes.

The average number of website visitors per day for the EADTU Open Distance Learning Universities is 69,490. On average, students spend about 9 minutes on digital educational platforms of these educational organizations.

\section{Discussion}

Social orientation is one of the basic principles of education in Europe. In all EU countries, open distance universities are supported by the state, while training in most cases is free.

Universities with open distance learning take care of their reputation and carefully select and validate content posted on online education platforms. If an online course is not in demand in the student environment, or less than $10 \%$ complete it, then such a course is usually removed [15].

In most European countries, training is usually conducted in English, online courses can also be presented in the native language.

\section{Conclusions}

The system of professional training of students in open distance universities is costantly being improved both in the content part and in issues of updating the forms of organizing the educational process: the development of e-learning using distance technologies, electronic teaching aids, the development of innovative digital solutions, the use of forms mobile learning [16].

The results obtained during the work and the analysis of the data obtained can be used to further study the experience of European open universities with distance learning and improve the quality and efficiency of open distance learning in Russia in the context of lifelong education. 


\section{References}

1. N.V. Lopatina, O.B. Sladkova, Measurement of Objects of digital Space in analytics of the Socio-Cultural Sphere. Scientific and Technical Information Processing, 43(3), 131-135 (2016)

2. E.V. Lyapuntsova, M. Vdovichenko, Y. Belozerova, A. Gorbatov, Application of modern modeling methods: virtual technologies in the era of digitalization and their role in modern com-panies. Journal of Physics: Conference Series. International Scientific Conference on Modelling and Methods of Structural Analysis, 1425, 012165 https://doi.org/10.1088/1742-6596/1425/1/012165 (2020).

3. J. Tsarapkina, A. Anisimova, S. Grigoriev, A. Alekhina, A. Mironov, Application of zoom and mirapolis virtual room in the context of distance learning for students. Journal of Physics: Conference Series. Krasnoyarsk Science and Technology City Hall, 12094 (Krasnoyarsk, Russian Federation, 2020)

4. N.V. Bystrova, E.A. Konyaeva, J.M. Tsarapkina, I.M. Morozova, A.S. Krivonogova, Didactic foundations of designing the process of training in professional educational institutions. Advances in Intelligent Systems and Computing, 622, 136-142 (2018)

5. S.M. Markova, S.A. Tsyplakova, C.P. Sedykh, A.V. Khizhnaya, O.N. Filatova, Forecasting the Development of Professional Education. Lecture Notes in Networks and Systems, 91, 452-459 (2020)

6. N.V. Kamenez, Z.V. Smirnova, O.I. Vaganova, N.V. Bystrova, J.M. Tsarapkina, Development of instructing techniques in professional training. International Journal of Mechanical Engineering and Technology, 10(2), 899-907 (2019)

7. S.A. Andel, T. de Vreede, P.E. Spector, B. Padmanabhan, V.K. Singh, G. Vreede, Do social features help in video-centric online learning platforms? A social presence perspective. Computers in Human Behavior, 113, 106505 (2020) https://doi.org/10.1016/j.chb.2020.106505

8. O.I. Vaganova, Z.V. Smirnova, N.S. Abramova, J.M. Tsarapkina, L.M. Bazavlutskaya, Current requirements for assessing the results of student training IOP Conference Series: Materials Science and Engineering, 012002 (2019)

9. A.A. Kuznetsov, S.G. Grigoriev, V.V. Grynshkun, Educational electronic publications and resources: methodic manual (2009)

10. S.M. Markova, M.N. Bulaeva, N.V. Bystrova, A.V. Lapshova, S.A. Tsyplakova, Economic Grounds for Integration of the Content of Vocational Education. Lecture Notes in Networks and Systems, 73, 759-766 (2020)

11. O.A. Nemova, T.V. Svadbina, E.K. Zimina, S.A. Tsyplakova, N.A. Shevchenko, E.A. Kostyleva, Professional orientation of youth: problems and prospects. Journal of Entrepreneurship Education, 20, 3 (2017)

12. J. Kasch, P. Van Rosmalen, M. Kalz, Educational scalability in MOOCs: Analysing instructional designs to find best practices. Computers \& Education, 161, 104054 (2021).

13. K. Khandwala, P.J. Guo, Codemotion: expanding the design space of learner interactions with computer programming tutorial videos. In Proceedings of the Fifth Annual ACM Conference on Learning at Scale (L@S '18), 57, 10 (New York, USA, ACM, Article2018) DOI: https://doi.org/10.1145/3231644.3231652

14. S.M. Markova, E.P. Sedykh, V.Y. Polunin, S.A. Tsyplakova, Modeling of Integrated Content of Professional Education for future Workers and Specialists. Lecture Notes in Networks and Systems Growth Poles of the Global Economy: Emergence, Changes and 
Future Perspectives, 1087-1095 (Plekhanov Russian University of Economics, Luxembourg, 2020)

15. M.G. Sergeeva, N.V. Romanova, S.E. Shishov, V.A. Kalnei, A.Yu. Lakhtin, Kh.A. Tonoyan, P.F. Kubrushko, Tutoring support of Learner Research Activity in the conditions of university education. RevistaDilemascontemporáne-os: Educación, Política y Valores. Year VII, SpecialEdi-tion, 2007-7890 (2019)

16. A. Mateia, C. Vrabie, E-learning Platforms Supporting the Educational Effectiveness of Distance Learning Programmes: A Comparative Study in Administrative Sciences. Procedia - Social and Behavioral Sciences, 93, 526-530 (2013) https://doi.org/10.1016/j.sbspro.2013.09.233 